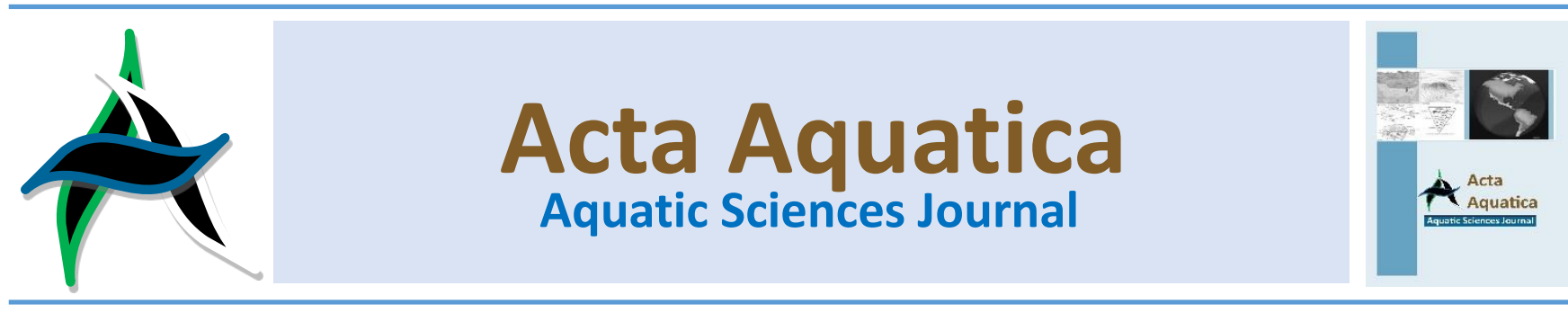

\title{
Pengaruh perbedaan sistem resirkulasi dan sistem konvensional terhadap pertumbuhan dan sintasan benih kuda laut (Hippocampus comes)
}

\section{The effect of using conventional system and recirculation system on growth and survival rate of seahorse fingerling (Hippocampus comes)}

\author{
Erlangga ${ }^{a}, *$, Zulfikar ${ }^{a}$ dan Syawaluddin Akbar ${ }^{b}$ \\ a Program Studi IImu Kelautan, Fakultas Pertanian, Universitas Malikussaleh, Aceh, Indonesia \\ ${ }^{b}$ Program Studi Akuakultur, Fakultas Pertanian, Universitas Malikussaleh, Aceh, Indonesia
}

\begin{abstract}
Abstrak
Tujuan penelitian ini adalah untuk mengetahui pengaruh penggunaan sistem resirkulasi dan sistem konvensional terhadap pertumbuhan dan sintasan benih kuda laut (Hippocampus comes). Manfaat penelitian ini yaitu untuk mengetahui perbedaan sistem resirkulasi dan sistem konvensional terhadap pertumbuhan benih kuda laut (Hippocampus comes). Metode yang digunakan dalam penelitian ini adalah metode eksperimen dengan menggunakan dua jenis perlakuan yang berbeda dengan 2 perlakuan 3 ulangan. Adapun Perlakuan yang digunakan adalah sebagai berikut :Perlakuan $A=$ Benih kuda laut dipelihara pada sistem resirkulasi Perlakuan $B=$ Benih kuda laut dipelihara pada sistem konvensional. Hasil penelitian menunjukkan bahwa pemeliharaan kuda laut dengan mengguanakan sistem konvesional daan sistem resirkulasi terdapat pertambahan bobot dan pertambahan panjang serta kelangsungan hidup yang normal atau sesuai. Pada pertumbuhan bobot sistem resirkulasi dengan berat $0,07 \mathrm{gr}$ dan panjang $0,63 \mathrm{~cm}$ serta kelangsungan hidup $100 \%$. Sedangkan pada sistem konvesional pertambahan bobot $0,05 \mathrm{gr}$ dan pertambahan panjang $0,58 \mathrm{~cm}$ serta kelangsungan hidup $60 \%$. Nilai kualitas air masih berada pada kadar optimum dengan suhu berkisar antara $26-27{ }^{\circ} \mathrm{C}, \mathrm{pH}$ berkisar antara 7,52-7,57 DO berkisar antara 6,04-6,16 ppm dan amoniak berkisar antara 0,121-0,262 ppm, nitrit 0,104-0,158 ppm.
\end{abstract}

Kata kunci: kuda laut; system resirkulasi; system konvensional; kelangsungan hidup

\begin{abstract}
The purpose of this study was to determine the effect of using conventional and recirculation systems on growth and survival rate of seahorse fingerling (Hippocampus comes). The benefits of this research are to find out the differences in recirculation systems and conventional systems for the growth of seahorse seeds (Hippocampus comes). The method used in this study is the experimental method using two different types of treatment with two treatments three replications. The procedures used are as follows: Treatment $A=$ Seahorse seeds are maintained in the recirculation system Treatment $B=$ Seahorse seeds are maintained in conventional systems. The results showed that the maintenance of seahorses by using conventional methods and recirculation systems had weight gain and normal or appropriate increase in length and survival. In the growth of the recirculation system weights $0.07 \mathrm{gr}$ and $0.63 \mathrm{~cm}$ long and $100 \%$ survival. Whereas in conventional systems the weight gain is $0.05 \mathrm{~g}$ and the increase in length is $0,58 \mathrm{~cm}$ and survival is $60 \%$. The value of water quality is still at optimum levels with temperatures ranging from $26-27 \mathrm{OC}, \mathrm{pH}$ ranges from 7.52-7.57 DO ranging from 6.04 to $6.16 \mathrm{ppm}$ and ammonia ranges from $0.121-0.262$ ppm, nitrite 0.104- 0.158 ppm.
\end{abstract}

Keywords: seahorses; recirculation system; conventional system; survival rate

\footnotetext{
* Corresponding author: Program Studi IImu Kelautan, Fakultas Pertanian, Universitas Malikussaleh. Jl. Universitas. Kec. Muara Batu, Kabupaten Aceh Utara, Provinsi Aceh, 20155, Indonesia.

Tel: +62-645-41373 Fax: +62-645-59089

e-mail:erlangga@unimal.ac.id

doi: https://doi.org/10.29103/aa.v6i2.1637
}

\section{Pendahuluan}

Indonesia cukup terkenal dengan komoditas perikanan laut yang berharga baik untuk tujuan penangkapan dari marikultur. Produk hasil laut Indonesia masih dikenal antara yang paling besar dan terbaik di nusantara ini. Pemerintah Republik Indonesia juga telah mengamanatkan sektor perikanan khususnya perikanan budidaya sebagai salah satu pilar dalam 
agenda membangunkan negara (Departemen Kelautan dan Perikanan, 2005). Antara cabang budidaya laut yang paling menguntungkan dan diusahakan dengan bagus oleh negara ini ialah perusahaan ikan hias. Menurut Syafiuddin (2010) dalam Permana (2014), salah satu ikan hias yang tinggal di kawasan pantai mempunyai nilai ekonomis yang tinggi dan populasi yang banyak di perairan Indonesia ialah kuda laut.

Kuda laut merupakan salah satu jenis komoditas ikan laut yang potensial untuk dibudidayakan. Kuda laut ditangkap dan diperjual belikan bukan hanya sebagai ikan hias, tetapi juga sebagai bahan obat-obatan tradisional. Kuda laut yang digunakan sebagai ikan hias diperjual belikan dalam keadaan hidup, sedangkan untuk bahan obat-obatan dijual dalam keadaan mati (kering) yang harga perkilonya mencapai 2 juta rupiah di pasaran Hongkong atau Cina (Vincent, 1996). Kuda laut ternyata bukan hanya terkenal di benua Asia, tetapi juga diperdagangkan di Afrika, Australia, Eropa dan Amerika Utara serta Latin.

Kuda laut memiliki keunikan morfologi yang merupakan kombinasi kepala kuda yang bermoncong dan bermahkota, badan ikan yang bersirip serta dilengkapi dengan ekor panjang seperti ular, dan secara keseluruhan tubuh mirip makhluk mitos yaitu naga. Menurut Ari et al. (2005) dalam Handri (2013), bentuk tubuh yang unik, warna tubuh cerah, gerakkan gemulai seperti jinak bila dipelihara menjadikan kuda laut sangat populer sebagai ikan hias air laut. Hal tersebut menyebabkan permintaan kuda laut semakin meningkat baik di pasar lokal maupun global.

Sebagai langkah untuk menjaga kelestarian kuda laut maka dilakukan upaya kegiatan penangkaran. Untuk mendukung kegiatan penangkaran salah satu faktor yang diperlukan adalah manajemen kualitas air, Manajemen kualitas air yang diperlukan disusahakan dengan kondisi yang optimal pada tahap pemeliharaan juwana dan pembesaran. Beberapa cara dalam pengelolaan kualitas air seperti melakukan penggantian air secara konvensional dan menggunakan sistem resirkulasi yang menggunakan berbagai macam filter yang berfungsi sebagai media untuk proses nitrifikasi.

Penggunaan sistem resirkulasi secara umum memiliki beberapa kelebihan yaitu: penggunaan air per satuan waktu relatif rendah, fleksibilitas lokasi budidaya, budidaya yang terkontrol dan lebih higienis, kebutuhan akan ruang/lahan relatif kecil, kemudahan dalam mengendalikan, memelihara, dan mempertahankan suhu serta kualitas air. Oleh karena itu, perlu diadakan penelitian mengenai pertumbuhan dan sintasan benih kuda laut $(H$. comes) dengan menggunakan sistem resirkulasi dan konvensional untuk menunjang usaha pembenihan kuda laut.

\section{Bahan dan metode}

\subsection{Metode penelitian}

Penelitian dilaksanakan pada bulan Maret hingga April 2018 bertempat di Laboratorium Kuda Laut Balai Besar Perikanan Budidaya Laut (BBPBL) Lampung yang terletak di Desa Hanura, Kecamatan Teluk Pandan, Kabupaten Pesawaran, Bandar Lampung.

Metode yang digunakan dalam penelitian ini adalah metode eksperimen dengan menggunakan beberapa jenis perlakuan yang berbeda dengan 2 perlakuan dan 3 ulangan. Perlakuan yang digunakan adalah:

Perlakuan A : sistem resirkulasi

Perlakuan B : sistem konvensional

\subsection{Prosedur penelitian}

\subsubsection{Persiapan wadah}

Desain sistem resirkulasi untuk pemeliharaan benih kuda laut ditunjukkan pada Gambar 1.

a).

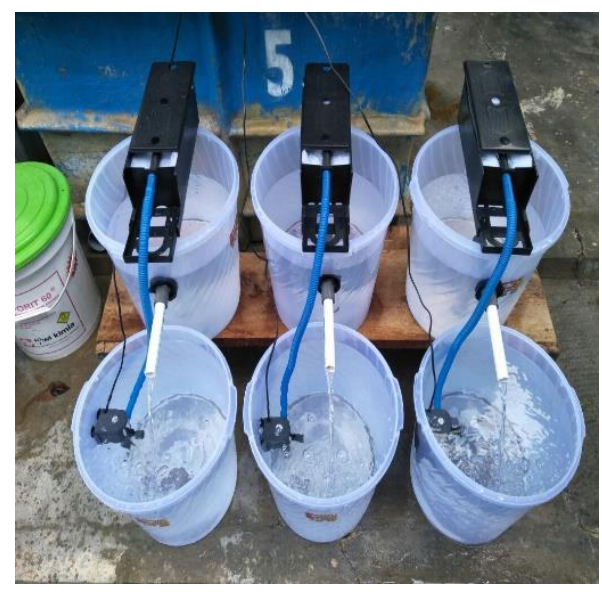

b).

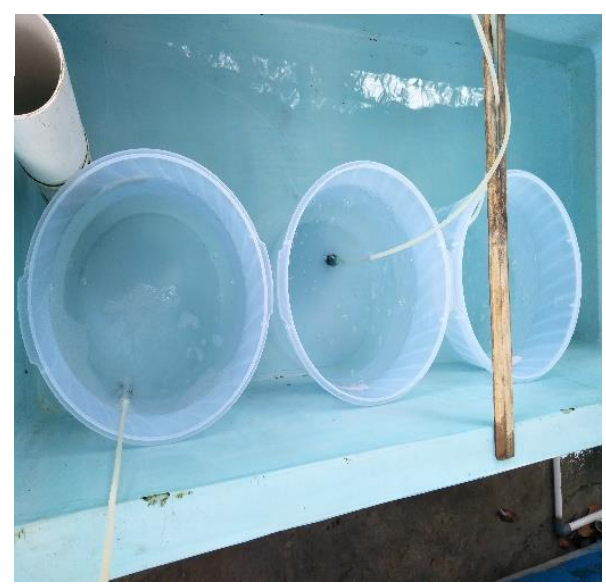

Gambar 1. Desain wadah penelitian. a.) sistem resirkulasi, b.) sistem konvensional.

\subsubsection{Pemeliharaan benih kuda laut}

Benih yang digunakan berumur 20-70 hari dengan ukuran minimal 3-5 cm dipelihara dengan memberikan pakan berupa artemia sebanyak 2 kali sehari pada pukul 08.00 dan 14.00 wib, dengan kepadatan Artemia 100 - 200 ekor/liter.

\subsection{Parameter pengamatan}

Parameter yang diamati selama penelitian adalah sebagai berikut:

\section{Pertambahan berat}

Pertambahan berat dihitung dengan menggunakan rumus menurut (Effendie, 1979 ) yaitu:

$$
\mathrm{W}=\mathrm{W}_{\mathrm{t}}-\mathrm{W}_{0}
$$

Keterangan:

$\mathrm{W}$ = pertumbuhan mutlak (gr)

$\mathrm{Wt}=$ bobot rata-rata akhir (gr)

Wo = bobot rata-rata awal (gr) 


\section{Pertambahan panjang}

Pertambahan panjang dihitung dengan menggunakan rumus (Effendie, 1979) yaitu :

$$
\mathrm{P}=\mathrm{P}_{\mathrm{t}-\mathrm{P}_{0}}
$$

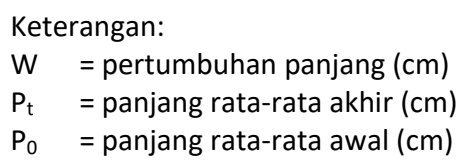

\section{Sintasan}

Sintasan benih kuda laut dihitung menggunakan rumus (Effendie, 1979):

$$
\mathrm{SR}=\mathrm{N}_{\mathrm{t}}: \mathrm{N}_{0} \times 100 \%
$$

Keterangan:

$\mathrm{SR}=\operatorname{sintasan}(\%)$

$\mathrm{N}_{0} \quad$ = jumlah benih pada awal penelitian (ekor)

$\mathrm{Nt}=$ jumlah benih hidup pada akhir penelitian (ekor).

\section{Kualitas air}

Kualitas air diukur secara periodik selama masa pengamatan. Pada penelitian ini nilai kualitas air yang diukur meliputi suhu, pH. DO, amoniak, dan nitrit.

\subsection{Analisis data}

Data yang diperoleh dari pengamatan akan disajikan dalam bentuk tabel dan grafik, kemudian di analisa dengan uji T berpasangan untuk menunjukan hasil yang berbeda nyata.

\section{Hasil dan pembahasan}

\subsection{Hasil}

\subsubsection{Pertambahan bobot dan panjang benih kuda laut (Hippocampus comes)}

Hasil penelitian menunjukkan bahwa perlakuan perbedaan sistem resirkulasi dan sistem konvensional berpengaruh terhadap pertambahan bobot mingguan pada kuda laut (Hippocampus comes) untuk lebih jelas dapat dilihat pada Gambar 2.

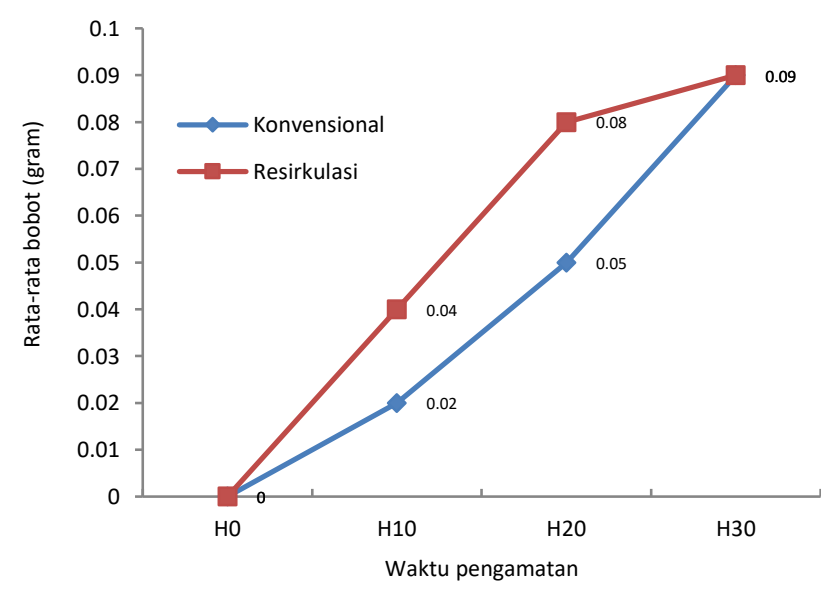

Dari grafik diatas dapat dilihat bahwa pada pemeliharan sistem resirkulasi pertambahan bobot kuda laut lebih tinggi dari pada pemeliharan kuda laut pada sistem konvensional dimana pada sistem resirkulasi rata-rata bobot pada minggu kedua mencapai 0,04 gr, minggu ke 3 mencapat $0,08 \mathrm{gr}$ dan pada minggu ke 4 rata-rata pertambahan bobot mencapai 0,09 gr. Sedangkan pada pemeliharaan sistem konvensional rata-rata pertambaan bobot pada minggu ke dua $0,04 \mathrm{gr}$, pada minggu ketiga 0,05 gr dan pada minggu ke 3 hanya mencapai 0,09 gr. Hasil uji statistik dengan menggunakan uji $t$ berpasangan menunjukan hasil yang tidak berbeda nyata (t hitung $(1.512<$ 0,05 (2.776) terhadap pertambahahan bobot benih kuda laut.

Pada penelitian ini pertambahan panjang kuda laut pada pemeliharaan sistem resirkulasi dan sistem konvensional berbeda antara kedua perlakuan. Dimana untuk lebih jelas dapat dilihat pada Gambar 3.

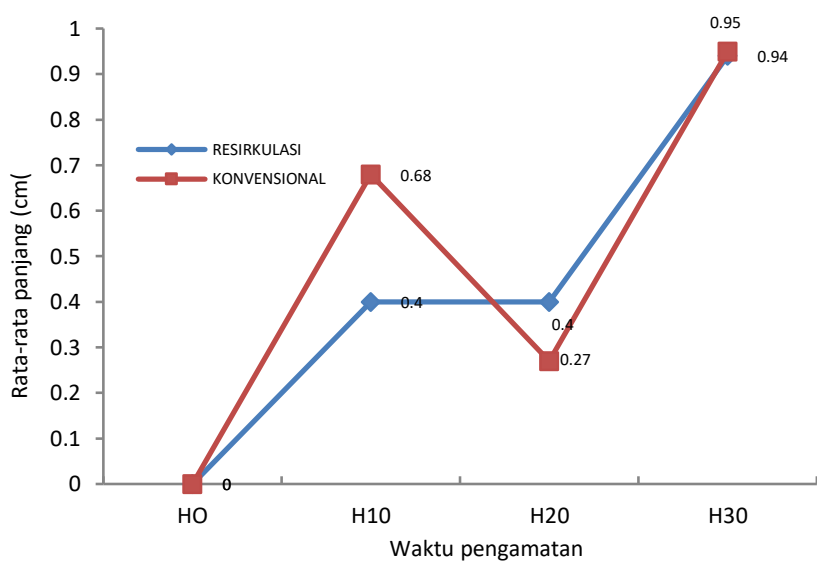

Gambar 3. Grafik pertambahan panjang mingguan kuda laut.

Grafik diatas dapat dilihaat bahwa pada pemeliharan sistem resirkulasi pertambahan panjang kuda laut lebih tinggi dari pada pemeliharan kuda laut pada sistem konvensional dimana pada sistem resirkulasi rata-rata panjang pada minggu kedua mencapai $0,68 \mathrm{~cm}$, minggu ke 3 mencapat $0,27 \mathrm{~cm}$ dan pada minggu ke 4 rata-rata pertambahan panjang kuda laut mencapai 0,95 gr. Sedangkan pada pemeliharaan sistem konvensional rata-rata pertambaan panjang pada minggu ke dua $0,40 \mathrm{~cm}$, pada minggu ketiga $0,40 \mathrm{~cm}$ dan pada minggu ke 3 hanya mencapai $0,94 \mathrm{~cm}$. Hasil uji statistik dengan menggunakan uji T berpasangan menunjukan hasil yang tidak berbeda nyata (Thitung $(0,780<0,05(2.776)$ terhadap pertambahahan panjang benih kuda laut.

\subsubsection{Sintasan benih kuda laut}

Hasil penelitian menunjukkan bahwa kelangsungan hidup benih kuda laut yang dipelihara dengan sistem resirkulasi lebih tinggi bila dibandingkan dengan pemeliharaan dengan sistem konvensional. Untuk lebih jelasnya dibawah ini gambar grafik sintasan juwana kuda laut.

Kelangsungan hidup Benih kuda laut selama penelitian pada sistem resirkulasi lebih tinggi bila dibandingkan dengan pada sistem konvensional. Dimana tingkat kelangsunagan kuda laut pada sistem resirkulasu mencapai $100 \%$. Sedangkan pada sistem konvensional hanya $60 \%$ saja. Hasil uji statistik dengan menggunakan uji $t$ berpasangan menunjukan hasil yang tidak berbeda nyata (t hitung $(2,619<0,05(2.776)$ terhadap sintasan benih kuda laut. 


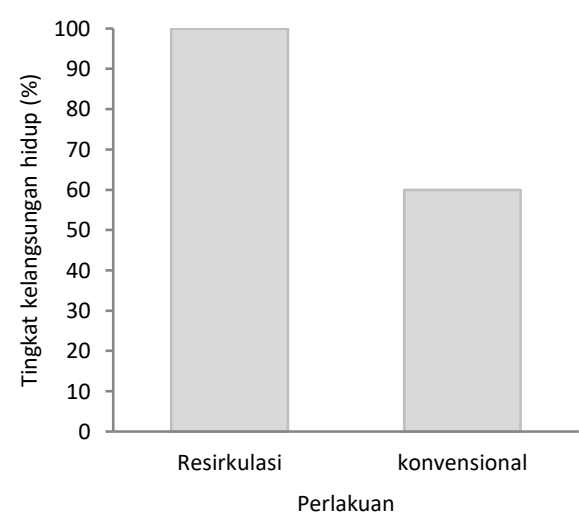

Gambar 4. Gafik tingkat kelansungan hidup benih kuda laut.

\subsubsection{Kualitas air}

Kualitas air merupakan hal yang sangat penting didalam budidaya biota air tawar maupun air laut karena jika kualitas air berada pada optimum biota yang dipelihara maka pertumbuhan dan kelangsungan hidup akan baik. Hasil pengukuran kualitas air selama penelitian nilainya masih berada pada kadar optimum pemeliharaan juwana kuda laut untuk lebih jelas dapat dilihat pada Tabel 1.

Tabel 1

Nilai parameter kualitas air pada perlakuan.

\begin{tabular}{lcc}
\hline Parameter & Resirkulasi & Konvensional \\
\hline Salinitas & $33-34 \mathrm{ppt}$ & $33-34 \mathrm{ppt}$ \\
pH & $7,52-7,57$ & $7,32-7,56$ \\
DO & $6,04-6,16 \mathrm{mg} / \mathrm{L}$ & $6,04-6,18 \mathrm{mg} / \mathrm{L}$ \\
Suhu & $26-27^{\circ} \mathrm{C}$ & $26-27^{\circ} \mathrm{C}$ \\
Nitrit $\left(\mathrm{NO}_{2}\right)$ & $0,104-0,158 \mathrm{mg} / \mathrm{L}$ & $0,104-0,158 \mathrm{mg} / \mathrm{L}$ \\
Amoniak $\left(\mathrm{NH}_{3}\right)$ & $0,121-0,262 \mathrm{mg} / \mathrm{L}$ & $0,121-0,266 \mathrm{mg} / \mathrm{L}$ \\
\hline
\end{tabular}

\subsection{Pembahasan}

\subsubsection{Pertumbuhan dan sintasan kuda laut}

Menurut Effendi (1979) pertumbuhan adalah resultan dari pertambahan panjang dan berat individu dalam suatu waktu. Bila jumlah energi makanan yang dicerna melebihi jumlah energi makanan yang diperlukan untuk mempertahankan hidup maka proses pertumbuhan akan berlangsung (Sastrawidjaja, 1992). Faktor yang mempengaruhi proses pertumbuhan yakni faktor eksternal dan faktor internal. Faktor eksternal meliputi salinitas, suhu, kuantitas pakan, $\mathrm{pH}$, kadar oksigen terlarut serta ruang gerak kuda laut. Sedangkan faktor internal terdiri atas: keturunan, ketahanan terhadap penyakit, umur, dan kemamampuan untuk memanfaatkan pakan.

Tingginya pertambahan bobot pada sistem resirkulasi diduga pada sistem resirkulasi kualitas media pemeliharaan lebih baik bila dibandingkan dengan sistem konvensional dengan menunjukkan nilai beberapa parameter yang sesuai untuk pertumbuhan dan sintasan juwana kuda laut. Diantaranya yaitu parameter kualitas air khususnya amoniak dan nitrit. Dimana nilai rata-rata amoniak selama penelitian pemeliharan kuda laut pada sistem resirkulasi yaitu $0,13 \mathrm{mg} / \mathrm{L}$, dan nilai rata nitrit yaitu $0,11 \mathrm{mg} / \mathrm{L}$. Kedua nilai ini tergolong kecil dan masih mampu untuk ditoleransi oleh kuda laut. Dan juga nilai ini tidak berpengaruh terhadap kehidupan dan pertumbuhan kuda laut. Sehingga nafsu makan dan tingkah laku juwana kuda laut masih dalam kondis normal.

Hal ini sesuai dengan pernyataan Hartati, (2009) yang menyatakan bahwa konsentrasi amoniak untuk pemeliharaan juwana kuda laut kurang dari 0,172 mg/L masih normal untuk kehidupan dan pertumbuhan kuda laut. Selain itu. Lockyear,
(1998) juga menyatakan bahwa beberapa faktor yang mempengaruhi proses pertumbuhan selain ketersediaan pakan yaitu faktor lingkungan meliputi salinitas, $\mathrm{pH}$, suhu, oksigen terlarut dan nilai amoniak yang stabil. Selanjutnya Al Qodri et al. (1997) mengatakan bahwa makanan merupakan faktor utama dalam menunjang pertumbuhan organisme.

Tingginya pertambahan panjang kuda laut pada sistem resirkulasi disebabkan karena apada perlakuan ini proses pengelolaan kualitas air lebih rumit sehingga air yang dihasilkan lebih berkualitas dari pada dengan sistem konvensional. Karena seperti diketahui bahwa apabila kualitas air yang digunakan untuk pemeliharaan kuda laut bersih maka kuda laut akan cepat berkembang. Selain itu juga benih kuda laut tidak stress dan akan mengkomsumsi pakan yang diberikan secara normal sehingga kecepatan tumbuhnya lebih cepat dibandingkan dengan pemeliharaan pada sistem konvensional. Hal ini sesuai denga pendapat Al Qodri et al. (1997) mengatakan bahwa makanan merupakan faktor utama dalam menunjang pertumbuhan organisme.

Sedangkan rendahnya pertumbuhan kuda laut pada sistem konvensional disebabkan oleh beberpa faktor diantaranya yaitu peningkatan kadar amoniak dan nitrit melebihi ambang atas sehingga tidak bisa ditoleransi oleh juwana kuda laut, Dimana nilai rata-rata amoniak pada pemeliharan dengan menggunakan sistem konvensional yaitu $0,23 \mathrm{mg} / \mathrm{L}$, dan nilai nitrit yaitu $0,14 \mathrm{mg} / \mathrm{L}$. Tingginya nilai amoniak pada perlakuan ini disebabkan oleh sisa pakan dan feses kuda laut. Peningkatan nilai amoniak terjadi pada minggu kedua dan ketiga.Sedangkan pada minggu pertama nilai amoniak masih dalam kondisi normal. Peningkatan yang melebihi ambang atas ini dapat menyebabkan nafsu makan berkurang dan juga bisa menyebabkan kematian pada benih kuda laut. Karena semakin tinggi nilai amoniak dan nitrit akan menyebabkan haemoglobin didalam darah menjadi met-haemoglobin dan akan mengurangi kemampuan darah untuk berikatan dengan oksigen.

Terhambatnya kemampuan darah untuk mengikat oksigen berakibat pada rendahnya jumlah konsentrasi oksigen didalam tubuh juwana kuda laut yang menyebabkan jaringan tubuh kekurangan oksigen dan menyebabkan kematian. Selain itu rendahnya konsentrasi oksigen didalam tubuh juwana kuda laut menyebabkan gerakan menjadi lebih lamban dan berakibat pada sulitnya memperoleh makanan. Hal ini sesua dengan pendapat Durborow et al. (1997) yang menyatakan bahwa paparan kadar nitrit dan amoniak yang tinggi pada darah organisme seperti ikan dapat menyebabkan terhambatnya proses transpor oksigen yang akan menyebabkan menurunnya nafsu makan dan menyebabkan kematian.

Sintasan juwana kuda laut selama penelitian pada sistem resirkulasi lebih tinggi bila dibandingkan dengan pada sistem konvensional. Dimana tingkat kelangsunagan kuda laut pada sistem resirkulasu mencapai $100 \%$. Sedangkan pada sistem konvensional hanya $60 \%$ saja. Tingginya tingkat kelansungan hidup juwana kuda laut pada sistem resirkulasi disebabkan karena kualitas media pemeliharaan yang baik dengan dan kualitas air masih berada pada ambang batas kehidupan kuda laut.

Sedangkan pemeliharaan kuda laut pada sistem konvensional mengalami penurunan disebabkan oleh kualitasa air yang kurang baik untuk kehidupan kuda laut itu dapat dilihat pada media pemeliharaannya banyak terdapat feses menumpuk pada dasar wadah. Sehingga menyebabkan kuda laut stres dan kehilangan nafsu makan dan menyebabkan banyak kematian pada benih kuda laut. Hal ini sesuai dengan pendapat Al Qodri et al. (1997) yang menyatakan bahwa makanan merupakan faktor utama dalam menunjang pertumbuhan organisme. Disamping makanan, jumlah makanan dan frekuensi pemberian pakan juga 
sangat berpengaruh terhadap pertumbuhan dan kelangsugan hidup kuda laut. Selanjutnya Lockyear, (1998) mengemukakan bahwa laju pertumbuhan akan sama apabila pada organisme yang berat dan panjangnya sama diberikan jumlah pakan yang sama.

\subsubsection{Kualitas air}

Kualitas air merupakan hal yang sangat penting didalam budidaya biota air tawar maupun air laut karena jika kualitas air berada pada optimum biota yang dipelihara maka pertumbuhan dan kelangsungan hidup akan baik. Pada penelitian ini nilai kualitas air yang diukur meliputi suhu, pH, DO, Amoniak, dan nitrit. Hasil pengukuran salinitas, suhu, DO, pH Amoniak, dan nitrit selama penelitian nilai kualitas air masih berada pada kadar optimum pemeliharaan juwana kuda laut.

Hasil penelitian menunjukkan bahwa kualitas air berada pada optimum pemeliharaan juwana kuda laut dan masih berada dalam standar baku mutu kualitas air, dimana nilai kualitas air yang didapatkan masih dalam range tersebut sehingga tidak mempengaruhi kehidupan juwana kuda laut.

Syafiuddin (2010) mengatakan bahwa suhu untuk pertumbuhan optimal juwana kuda laut berkisar antara $26^{\circ} \mathrm{C}$ $29{ }^{\circ} \mathrm{C}$ dan apabila oksigen terlarut kurang dari $3 \mathrm{mg} / \mathrm{L}$ dan berlangsung dalam waktu yang lama akan menyebabkan terhambatnya pertumbuhan dan berkurangnya nafsu makan ikan. Selain itu kurangnya oksigen terlarut menyebabkan aktifitas kuda laut menjadi menurun. Pada penelitian ini DO (oksigen terlarut) dikatakan sangat baik karena diatas $3 \mathrm{mg} / \mathrm{L}$ seperti yang dikatakan Syafiuddin (2010) dalam pemeliharaan juwana kuda laut jumlah oksigen terlarut yang optimal untuk pertumbuhan berkisar 5-6 ppm.

Menurut Nontji (1993) air laut memiliki nilai pH yang cenderung stabil dan nilainya berkisar 7,5-8,4. Pada $\mathrm{pH}$ yang rendah (keasaman yang tinggi). Gufran dan Kordi (2010) mengatakan dalam pemeliharaan juwana kuda laut nilai $\mathrm{pH}$ yang ideal berkisar 7-8. Hasil penelitian menunjukkan $\mathrm{pH}$ masih berada pada kisaran optimum pemeliharaan kuda laut. Pada penelitian ini amoniak berkisar antara 0,121-0,262 mg/L Menurut Hartati (2009) konsentrasi amoniak untuk pemeliharaan juwana kurang dari $0,172 \mathrm{mg} / \mathrm{L}$. Tetapi pada penelitian ini kadar amoniak masih dalam keadaan optimum. jika kadar amoniak 0,6 mg/L maka akan membahayakan biota yang dipelihara karena dapat meyebabkan toksik (Boyd, 1979).

\section{Kesimpulan}

Secara statistik tidak ada perbedaan pada pemeliharaan secara resirkulasi dan konvensional untuk pertumbuhan panjang dan bobot kuda laut (Hipocampus comes), tetapi terdapat pengaruh pada nilai sintasan kuda laut. Dimana pada sistem resirkulasi sintasan mencapai $100 \%$.

\section{Bibliografi}

Al Qodri, Sudjiharno A.H., Hartono, P., 1997. Rekayasa Teknologi Pembenihan Kuda laut Laut (Hippocampus spp). Ditjen Balai Budidaya Laut Lampung.

Boyd, C.F., 1979. Water Quality in Warm Water Fish Pond. Auburn University. Alabama

Departemen Kelautan dan Perikanan, 2005. Pembenihan Kuda Laut. Balai Budidaya Lampung: Indonesia.
Effendie, M.I., 1979. Metode Biologi Perikanan. Yayasan Dewi Sri. Bogor.

Ghufran, M., Kordi, K., 2010. Panduan Lengkap Budidaya Kuda Laut. Ikan Unik Yang Berpotensi Obat. Lily Publisher. Yogyakarta.

Lockyear, J., 1998. Studi Pendahuluan Pemijahan di Bak Terkontrol dan Pembesaran Kuda Laut KNYSNA (Hippocampus copensis). Departement of Ichthyology and Fisheries Science Rhodes University. Graham Stown. South Africa.

Nontji, A., 1993. Laut Nusantara. Djambatan. Jakarta.

Permana, B.S., 2014. Teknik Pembenihan Kuda Laut (Hippocampus comes) di Balai Besar Pengembangan Budidaya Laut Lampung, Pasawaran - Lampung. Praktek Kerja Lapangan. Program Studi Budidaya Perairan Jurusan Manajemen Sumberdaya Perikanan. Universitas Brawijaya: Indonesia.

Sastrawidjaja, T.M.F., 1992. Pengaruh Pemberian Ransum Uji Dengan Kadar Protein. Aneka Ilmu, Semarang.

Syafiuddin, 2010. Studi Aspek Fisiologi Reproduksi: Perkembangan Ovari dan Pemijahan Kuda Laut (Hippocampus barbouri) Dalam Wadah Budidaya. Disertasi. Program Studi Ilmu Perairan Pascasarjana. Institut Pertanian Bogor: Indonesia.

Vincent, A. C. J., 1996. The International Trade in Seahorses. Department of Zoology. University of Oxford: United Kingdom. 